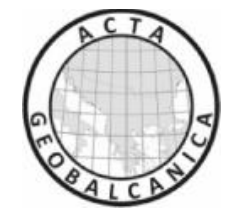

\title{
TRANSFORMATION FROM STATE SOCIALISM TO MARKET ECONOMY; EFFECTS ON AGRICULTURAL PRODUCTION AND RURAL LANDSCAPES IN ESTONIA AND LATVIA
}

\author{
Professor emeritus Dr. Philos. Arild Holt-Jensen \\ Department of geography, University of Bergen, Norway \\ Corresponding author: sggah@geog.uib.no
}

\begin{abstract}
A prominent feature in present day Estonia and Latvia is large tracts of formerly productive land laid idle and production buildings of collective farms in ruins. However, in some areas most farmland is actively used. An investigation of possible landscapes of action, both for the national decision makers and the single landowner is needed in order to understand recent transformations. The empirical focus is on the local responses to the restructuring/restitution measures adopted by the Estonian and Latvian governments in the 1990s and the resulting effects on the cultural landscape and the agricultural development. Restitution was politically necessary, but it has had a number of unexpected effects on landscape development and agricultural production. New 'speculative' land use patterns of urban sprawl around the larger cities, with negative effects on agricultural landscapes, are among these. On the other hand, where large production units could be formed as capitalist enterprises and where agricultural land is good, agricultural production is maintained. The actual, local landscape development is, however, a result of local responses to general processes. The focus of this study is on how individuals and local communities interpret opportunities and obstacles set by personal ambitions, local conditions and general policies. The study is limited to some few selected case studies in Estonia and Latvia. The cases represent quite different results, and the reasons for this has been analysed.
\end{abstract}

Keywords: Cultural landscape change, restitution, production unit, transition economy, large and small scale farming;

\section{INTRODUCTION}

The Estonian and Latvian rural landscape has partly been shaped by large production units such as manors, collective farms and capitalist enterprises. Small-scale farming has been seen as an ideal, but dominated rural land use only in the short period 19191940. The pre-1850 period was characterised by noblemen's landed estates and associated villages. Although under Swedish and later Russian rule the majority of the estate owners had been of German origin since $13^{\text {th }}$ century. The German merchants also dominated the major cities as Hansa towns. The tsar abolished serfdom in Estonia and Latvia 1816-19, and a cultural awakening with newspapers and books in Latvian and Estonian started in the 1840s. As long as the Russian tsars were liberal and accepted Lutheranism and Latin alphabet the national fight was against the cultural and economic dominance of the Baltic Germans, rather than to demand independence from Russia. 
When Estonia and Latvia became independent republics in 1918, after the collapse of the Russian tsarist rule, the first action taken was to expropriate the $50 \%$ of farmland still belonging to the nobility. The land reforms of the 1920 s aimed at creating farm units with ca. 24 ha per household of which half should be arable [4]. But demand was great and smaller units were established were former tenants lived in villages, such as on Vormsi (Fig. 1).

The freehold period dominated, however, only from 1920 till 1940. During WW2 the Baltic states became a shifting warzone between Soviet Union and Nazi Germany. Estonia lost $20 \%$ and Latvia $25 \%$ of its population. Many fled the country and others were sent to Siberia. After annexation into the Soviet Union a massive migration from Russia started to make up the workforce in the Soviet-initiated industries. In Estonia the Russian ethnic minority grew from $8 \%$ in 1940 to $27 \%$ in 2007, in Latvia from $9 \%$ till $29 \%$. The Russian ethnic population is mainly concentrated in the capital cities and some larger towns.

Collective and state farms were created by Soviet power 1949-50. The total number of units in Estonia were initially ca 2400 in 1950, but had been reduced to 317 large units by 1988. Urban dwellers and collective farm workers were allowed to have a small piece of colony garden land ('datcha'). Freehold farms were eradicated. [2].

\section{RESTITUTION}

When Estonia and Latvia regained independence in 1991, one of the first acts was denationalisation of property. Peil [4] discusses the role of rural landscape for the national identity. Rurality and the narrative of the land have played important roles in imagination of the homeland. Although the land had been owned by 'foreigners' the majority of the ethnic Estonians and Latvians worked the land. In Latvia a large single big oak standing in the middle of a field became a symbol and was printed on the paper money till they shifted to Euro. 'Land restitution was to strengthen the bond between the people and the land, indicating that the ideal of the small farm had survived throughout the Soviet Period. [5]. Restitution involved the return of property rights to pre-Soviet owners or their heirs whose land had been expropriated through nationalisation and collectivisation. In Estonia restitution was intended for all farmland, in Latvia it also included former farmland which had been taken into use for urban development. Restitution was also carried out for urban multifamily dwellings that had been built before 1940 and nationalised under Soviet rule.

Even if restitution was a simple political aim, the policies carried out had to include many compromises. The speed was not rapid, as it could be delayed by several factors, such as paper-processing abilities of claimants and legal disputes among the descendants of pre-war owners. Justice was the prime consideration, leaving aside economic and practical factors. In many cases the heirs of a 1940-farm had no relations to farming, being urban workers. A special case was the island of Vormsi (Fig.1). The island and some other west coast areas in Estonia had been settled by Swedes from $13^{\text {th }}$ century and the population still spoke Swedish in 1940. In 1944 more than $90 \%$ of the 2500 Swedish speaking at Vormsi left their farms and fled to Sweden and did not come back. In 1991 the Swedish heirs were offered the possibility to take back the originally small village farms of their grandparents. As one of our case studies we carried out field 
investigations at Vormsi in 2008 and 2014 to find out what had happened to the land and production since 1991.

\section{METHODOLOGICAL APPROACH}

Initially it was important to get a general overview of the change in number of production units and the land use development since 1991. It was also important to find data on the use of EU agricultural support after Estonia and Latvia joined EU in 2004, and the impact this has had on land use in different types of land areas. But our most prominent approach was to carry out detailed case studies using qualitative interviews with farmers and decision makers. A great number of case studies have been carried out partly by the present author, but mainly by students taking part in field courses in Estonia and Latvia from 2005 till 2014. In this paper there is only space to present 2 case studies in some detail; Vormsi Island and Surju Municipality, both in Estonia (fig.3).

\section{FROM RESTITUTED SMALL FARMS TO LARGE SCALE AGRIBUSINESS}

Enthusiasm over restitution and private farm re-establishment lasted only a few years and was replaced by rural recession in the 1990s. One reason was that many restitutees lacked farming qualifications. A second reason was the lack of proper equipment and farm buildings on most of the small, old units. The legacy from the Soviet period were large production buildings and poor blocks of flats for the collective farm workers. These were of little use to the restitutees. Further the government did not offer any special subsidised loans or support for the small-scale farmers. In addition the Baltic farmers lost the large market in Russia, particularly in St Petersburg, which was very important before 1991. Prices gained on farm products as milk and meat fell dramatically. Close to the larger urban centres many of the restitutees did not even try to start farming, but rather hoped that the land could be sold to suburban housing developers or industries. In many rural suburbanising areas, one can find 'wounded landscapes', where agricultural land use has ceased while new suburban land use is not completed. Overgrown plots 'for sale' became particularly a feature after the 2008 economic recession. In case studies we carried out in Sauga, a suburban municipality bordering the town of Pärnu, we found that only two active farmers worked the land in 2009, and they survived because they had extended their agricultural land buying or hiring land from restitutees that had not taken up agriculture. Less than $20 \%$ of the agricultural land used in Sauga 1989 was in agricultural use in 2009. This is, however an extreme case, at an average 10-20\% abandonment is seen in both Latvia and Estonia. Abandonment mainly occurred under the agricultural recession in the 1990s.

In the $21^{\text {st }}$ century transition from small to large units became dramatic. Raagmaa [2] analysed the change in Estonian agricultural units 2001-2007. The total number of holdings was reduced with 58\% between 2001 and 2007 (from 55702 to 23257 units). Only size classes above 50 hectares agricultural land increased. But agricultural land in use increased with $4 \%$ in the same time period, abandonment had stopped. The same trend of growth in agribusinesses is found in Latvia. In 2013 we carried out a case study in the municipality of Baltinava in Eastern Latvia on the border to Russia and visited a large Latvian owned agribusiness which used as much as 2500ha of land for production of mainly grains and employed 25 agricultural workers. This unit had improved and extended the production buildings of a collective farm from Soviet time. 
In our case study of Tori municipality (Fig.3) restitution had been carried out and most of the agricultural area was in active use, but in most cases not by the original restitutees. We carried out interviews with owners of 4 large units, but actually they only owned from $13 \%$ to $31 \%$ of the land they tilled, the rest were hired from restitutees that had given up agriculture. While the four large collective farms that existed in Soviet time had their land in one connected area, the present farmers had much land scattered in many plots, some even located in other municipalities. The transformation of the Soviet system via small scale restituted units and back to larger agribusinesses seemed not to have created better agricultural units [2].

In a Latvian study [3] land use changes were mapped in a number of different agricultural areas using ArcGIS software analyses of older maps and orthophotos from the first part of $21^{\text {st }}$ century. One main aim was to analyse the relations between land use (and abandonment) and the support farmers could get from EU Common Agricultural Policy after 2004, when both Estonia and Latvia became EU members. A general conclusion was that the land abandonment, followed by re-colonisation by woodland, was really fast before Latvia joined EU. The Common Agricultural Policy has so far not stopped or reversed this process. One example is Nautrênupagasts in the Eastern Latvian lowlands. From early $20^{\text {th }}$ Century, when most of the land area was used for agricultural production, a significant abandonment and transition to forest was registered in 2000, particularly in the southern hilly section. Agricultural land use had become concentrated to the fertile and flat land in the central part of the study area. The EU SAP applications in 2006-2007 were also mainly used by farmers on the plains in the central part of the study area, whereas SAP applications were significantly fewer in the marginal, hilly areas. Nikodemus [3] found that most of the farmers used the support schemes for maintaining the open landscape and not for intensive agriculture.

The other Latvian case studies [3] generally confirmed that EU support favoured the use of the best and flat agricultural land, and had no impact in preserving the mosaic-type cultural landscapes so typical for Latvia. Landscapes most at risk, as undulating uplands and river valleys, are left to overgrowth with shrubs and forest, even though preservation of such cultural landscapes is stated as a European aim.

With reference to Estonia Holt-Jensen \& Raagmaa [2] state that when the EU's Common Agricultural Policy came into effect, large enterprises increased their profitability and competitiveness. These enterprises focused mainly on production and efficiency without much regard for landscape consequences. Due to higher efficiency, they released a majority of the workers formerly employed by collective farms, causing unemployment and out-migration. Consequently many farm buildings and blocks of flats on former collectives have been abandoned.

Another aspect is that a number of farms in the more fertile areas have been bought by foreign farmers who are keen to maximise the productivity. Nikodemus [3] wonder if the motivations and dynamism of the farmers may be even more important than the land quality. They point out that for instance Danish farmers who buy farmland in Latvia are well educated and have good experience in making use of agricultural support systems. 


\section{VORMSI, SWEDISH RESTITUTION AND SECOND HOME DEVELOPMENT}

Before WW II ca 7000 citizens of Swedish ethnicity were settled in rural areas, particularly on the islands Vormsi, Pakri, Naissar, Osmussar and the peninsula Noaroosti in the northwest and on the small island of Ruhnu in the Riga Bay (see fig.3). The Swedish community had existed since medieval times. Originally there were 12 villages on Vormsi where the inhabitants tilled the land in a communal system and additionally lived from fishery and seafaring. Swedish rule over Estonia from $1561 \mathrm{did}$ not benefit the earlier Swedish freeholders as the island was given as a royal gift to one of the military leaders. One of the villages was destroyed and Magnushov Manor established. The village farmers became serfs with curvée duties at the manor. As long as Estonia was ruled by Sweden the farmers of Swedish ethnicity were treated slightly better than the Estonian serfs on the mainland, but in 1719 Estonia came under Russian rule and a Baltic German baron came to rule at Magnushov. In the $19^{\text {th }}$ century the baron's rule was broken and the farmers became freeholders. [7]. However, in 1944 the whole Swedish population of 2500 became boat refugees to Sweden, and were soon integrated there.

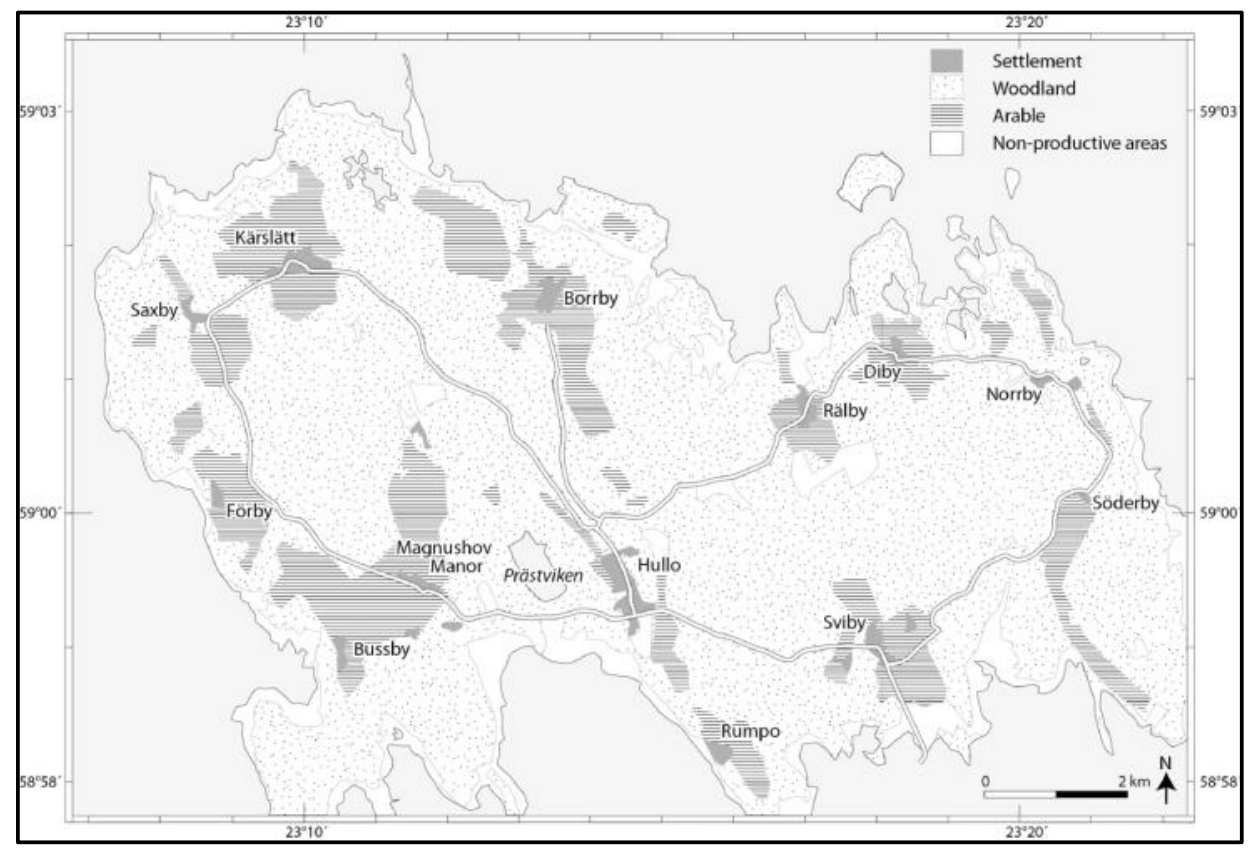

Figure 2. Vormsi

In 1945 the population was 912, mainly Estonian speaking and the agricultural land was amalgamated in one collective farm which in 1991 had the production buildings close to the community centre at Hullo. The collective farm had, however, to use the scattered agricultural land in each village and village dwelling houses continued to be used by the collective farm workers. In 1991 when the Swedish heirs were offered to take back the village farms on restitution this was an asset; the dwellings needed repair but many could be lived in. But even before WW II the single village farm could hardly provide for family survival, supplementary incomes from fishery and seafaring had been needed. The Swedish restitutees soon found they could not leave good jobs in Sweden 
and settle permanently on Vormsi. Some pensioneers decided to settle, but mostly the grandparent's old farms could at best be transferred to second homes for vacations.

In a student field study [1] detailed mapping and a number of interviews in the three villages Kärslätt, Borrby and Rälby were carried out. In 1934 Kärslätt had 292 inhabitants, Borrby 335 and Rälby 152. In 2014 the 'winter population' was very small. Borrby had only one household with 2 people in winter, in Rälby there were 12 winter residents and in Kärslätt 10. 'In winter the life stops, because the summer people are away', one informant said. In summer more than 40 stayed in Borrby, more than 60 in Rälby and 30 in Kärslätt. On the whole island only about 200 people, mostly old people, live there all year, whereas in summer the population rose to ca 1000. The property owners could be divided in permanent residents, summer residents and Swedes. Prior to the field study we expected, due to historical legacies, to find many Swedish second home owners. But in 2014 the majority of second home owners proved to be Estonian, and only a smaller group Swedish. It was found that many Swedish families that became restitutees in the 1990s had sold their properties to Estonians. The permanent residents have family ties to many of the Estonian summer house owners, whereas 'you barely see Swedish people here, they come here rarely and don't speak much to the local people' as one informant said. The island is 'Estonian' now, Swedish restitution was mentally a failure for the Swedes. It was also a failure as regards agricultural production; the former pasture land has become thickly overgrown with juniper bushes and is transforming to forest. Only small parts are in agricultural or garden use. But the island is attractive for recreation also because most summer homes are located in the villages and no massive recreational projects have developed. In the small shop at Hullo we even found locally produced Vormsi beer and also high quality local fruit wine.

\section{SURJU MUNICIPALITY; COLLECTIVE FARM TRANSFORMED TO NEW AGRIBUSINESS}

The situation in Surju, a municipality west of the town of Pärnu, is quite different from that on Vormsi and also differs from the case studies Holt-Jensen \& Raagmaa [2] carried out in Tori and Sauga, shortly commented upon earlier. In Soviet time all of the arable land in the municipality belonged to one large collective farm. This was surrounded by forests and mires mainly in state ownership. The collective farm had in its centre quite modern building complexes, including barns for ca 1000 dairy cattle. The landscape has not changed very much from 1991 till present; only $15 \%$ of the arable land is abandoned. Farming is still practised in one unit, using the cowsheds of the former collective farm along with some new ones. The director of Surju Farm told that they utilised 1300 ha of which 800 ha is grazing land. The number of cattle in 2009 was ca 1000, the same number as at the former collective farm, and $80 \%$ of the income is from the sale of milk. The first years after 1991 were very difficult as the price of milk was extremely low due to the loss of the Russian market, and as the collective farm was supposed to be divided between 260 restitutees. A dispute started between the leaders of the collective farm and the restitutees. Many of the latter were proud to get back the land of their forefathers and wanted to keep it. On the other hand the local 
workers on the former collective wanted to keep their jobs and the leaders in the local community felt they had someresponsibility in providing employment. In the end Surju Farm was established and bought out some of the restitutees, while the majority rented their land to the large farm and some of them found work there too. Only four restitutees ('not rented' on fig.2) decided to keep their land for themselves.

It has been possible to modernise and rationalise production. In the Soviet period the collective had 230 workers, in 2009 Surju Farm was run with only 42 workers. Surju Farm is a good example of a locally owned agribusiness that has the possibility of surviving. In 2009 there was a problem with falling milk prices due to competition from other European countries. The animal-breeding at the farm seems effective, but fodder production is limited, mainly concentrating on hay, ensilage and pasturing. There should be possible for the farm to produce fodder grains, rape (Brassica napus) and other valuable crops.

Many factors contributed to the successful transition of Surju Collective to Surju Farm. The former leaders of the collective farm were respected local people; trust was a major factor. Secondly the farmland formed a large connected area (fig.2), not scattered as the village farmlands on Vormsi. 


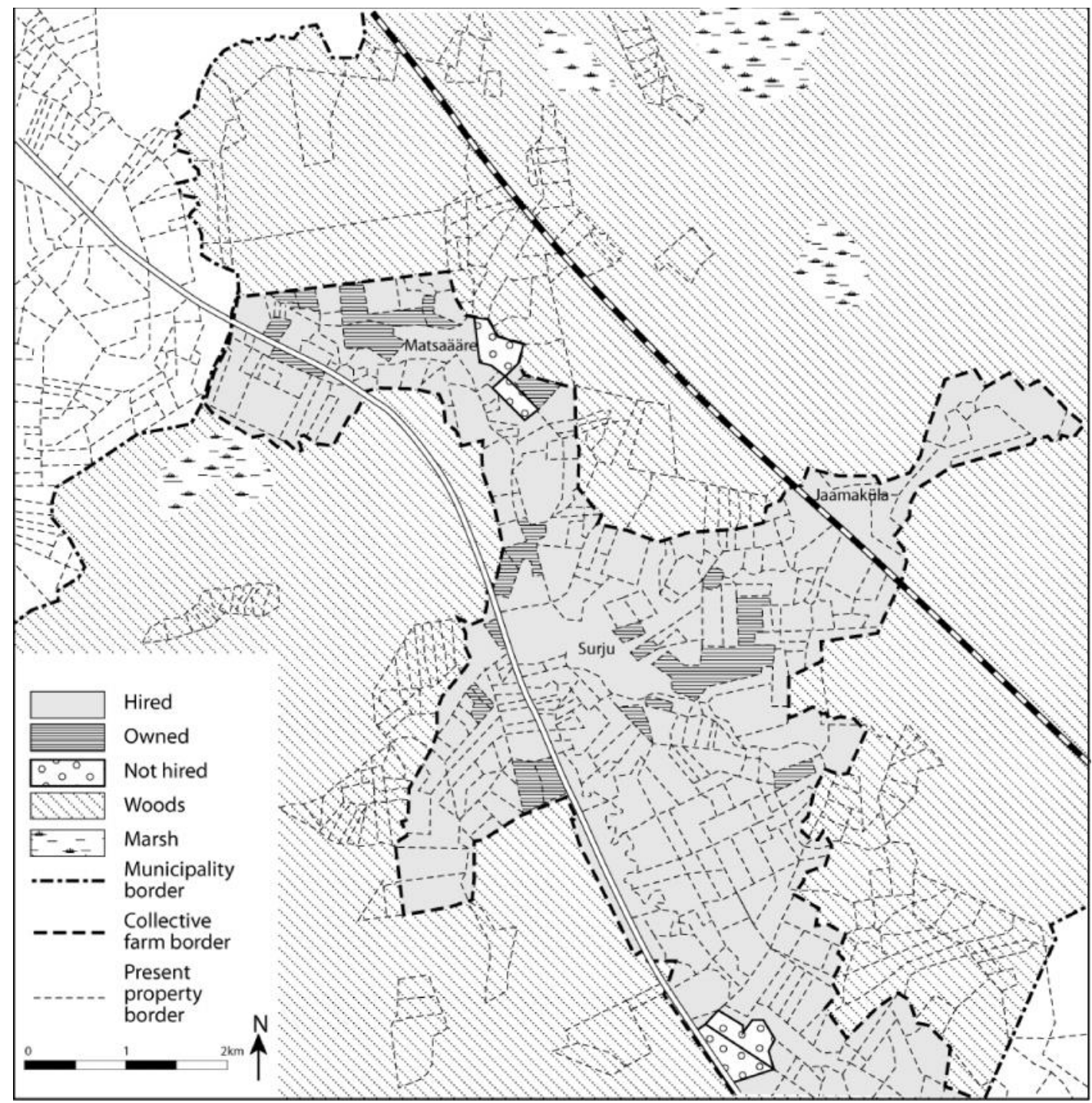

Figure 2. The central parts of Surju municipality with property situation in 2009.

\section{CONCLUSIONS}

Our studies confirm that the historical legacies of large production units such as manors and collective farms are now followed by capitalist agribusinesses. Even the relatively large family farms we investigated have problems to survive and fear absorption by large international agribusinesses, mainly because they depend on renting most of the land they depend on. The effects of the EU common agricultural policies are working in the same direction; most of the farmers we interviewed stated that applications for agricultural support were complicated and only useful for large producers. As documented in the Latvian study [3] many small scale farmers do not bother to apply for EU SAP support. In Latvia in 2002 as many as $67 \%$ of all farms produced no output for sale and only some $20 \%$ sold more than $50 \%$ of their output, the rest being consumed on the farm.

It is a clear tendency that farm types increasingly become polarised into large scale agribusinesses on the one end of a scale and small subsistence farmers at the other, with 
very little in between. Restitution of agricultural land was a political necessity in the 1990s, but in hindsight it was not wise in relation to landscape development and agricultural production.

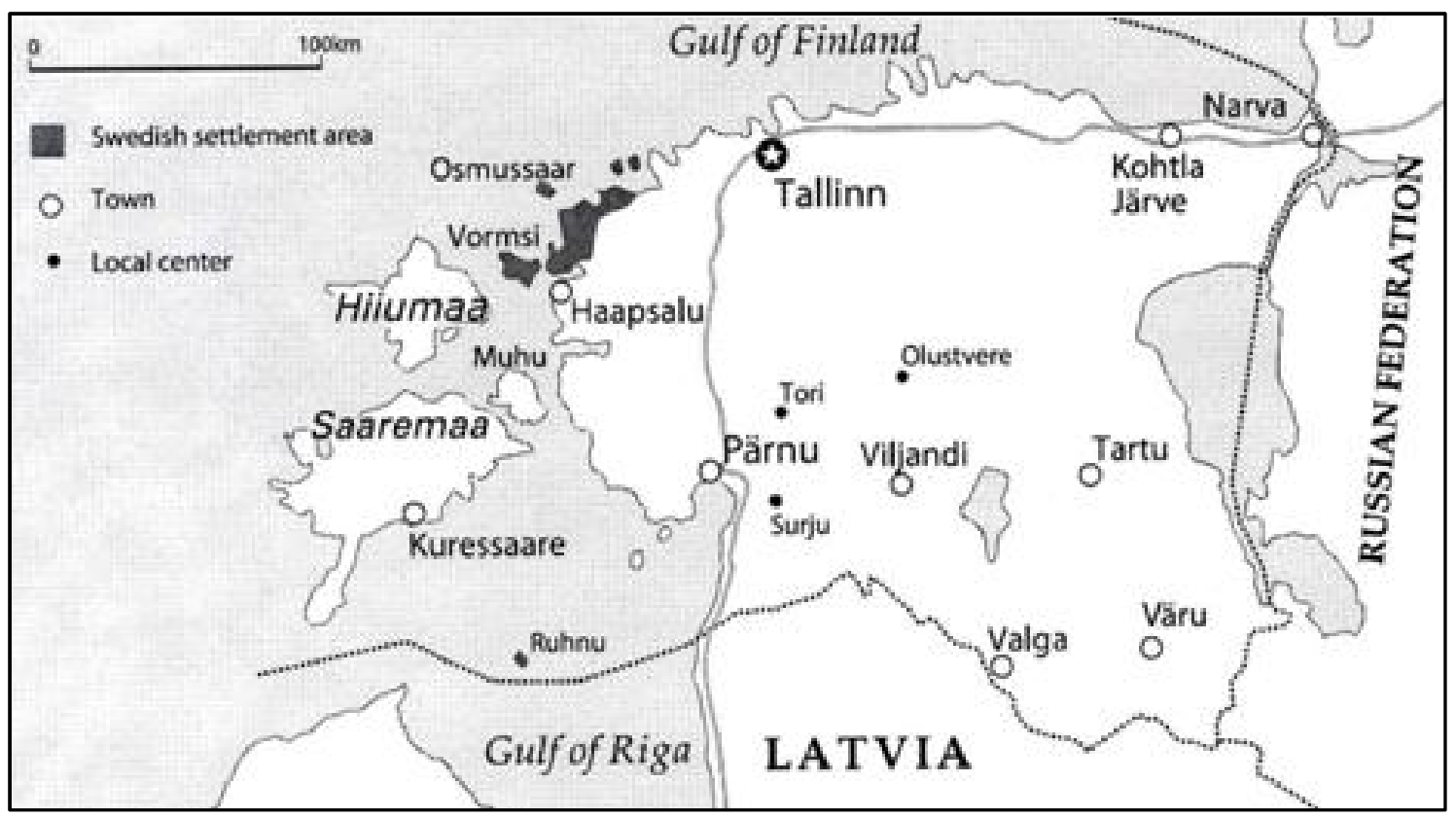

Figure 3. Estonia with locations of some of the case study areas and old Swedish settlements

\section{REFERENCES}

[1] Ausdal, C., Khanal, B., Raun, J. \& Ruberg,G. (2014): Effects of the presence of the temporary residents on permanent residents lives - case study of Vormsi island. NORD+14 Student field course report.

[2] Holt-Jensen, A. \& Raagmaa, G. (2010): Restitution of agricultural land in Estonia: consequences for landscape development and production. Norwegian Journal of Geography,64,129-141.

[3] Nikodemus, O., Bell, S., Peneze, Z. \& I.Krüze (2010): The influence of European Union single area payments and less favoured area payments on Latvian landscape. European Countryside, 1 2010, 25-41.

[4] Peil, T. (1999): Islescapes. Estonian small islands and iselanders through three centuries.Almquist\&Wiksell International, Stockholm

[5] Peil, T. \&Sooväli, H. (2005): Estonian national landscapes - the sum and its parts.

[6] In Peil, T. \& Jones, M. (eds): Landscape, Law and Justice. Institutt for sammenlignende kulturforskning. Serie B: Skrifter 118, 49-60. Novus Forlag, Oslo.

[7] Svärd, S. (2007): Kärrslätt - Min By. Trio Tryck, Örebro 